\title{
Reconstruction. Introduction
}

Salhia Ben-Messahel and Kathie Birat

\section{(2) OpenEdition}

1 Journals

Electronic version

URL: http://journals.openedition.org/ces/293

DOI: $10.4000 /$ ces.293

ISSN: 2534-6695

\section{Publisher}

SEPC (Société d'études des pays du Commonwealth)

\section{Printed version}

Date of publication: 1 April 2018

Number of pages: 81-83

ISSN: 2270-0633

\section{Electronic reference}

Salhia Ben-Messahel and Kathie Birat, "Reconstruction. Introduction", Commonwealth Essays and Studies [Online], 40.2 | 2018, Online since 05 November 2019, connection on 03 April 2021. URL: http:// journals.openedition.org/ces/293; DOI: https://doi.org/10.4000/ces.293

\section{(c) (i) () $\ominus$}

Commonwealth Essays and Studies is licensed under a Licence Creative Commons Attribution - Pas d'Utilisation Commerciale - Pas de Modification 4.0 International. 


\section{Reconstruction \\ Introduction}

The theme of the 2017 SAES conference "(Re)construction(s)" is particularly pertinent in the area of colonial and postcolonial studies, for it captures one of its underlying preoccupations. It suggests that the ultimate purpose of postcolonial deconstruction - which represents a first step toward a transformation of critical thought that aims at overcoming Eurocentric approaches to space, place, people, and nations - is reconstruction. By incorporating other voices, postcolonial deconstruction challenges Eurocentric practices, but in giving voice to those subaltern and colonised subjects it functions as a form of postcolonial reconstruction. In an article entitled "The Afterlives of Frantz Fanon and the Reconstruction of Postcolonial Studies," Bahkti Shringarpure notes that recent conflicts in former colonies have triggered a renewed interest in the work of Frantz Fanon, especially his book The Wretched of the Earth, and says:

More than half a century after his death, the specter of Frantz Fanon haunts the field of postcolonial studies, and his reflections on decolonization, nationalism and violence seem more poignant than ever. Part of the reason is that, instead of a successful transition into nation-states, several of the ex-colonies have become sites for terrible conflicts in the name of ethnicity, race, power, religion and territory. (113)

Thus, in the light of postcolonial contexts, re-reading Fanon's work most certainly reminds us that the dream of decolonization has not been completely fulfilled, and that we need to reflect again on Fanon's claims concerning violence and the negation of otherness.

The articles presented in the workshop devoted to New Literatures approach the idea of reconstruction from a variety of perspectives, involving both thematic concerns and the aesthetics involved in reconstructing an artistic vision of subaltern populations. They remind us that reconstruction involves a rereading of the past, of both time and space, as a necessary preparation for the construction of a more promising future. Three of the articles published here (Zinck, Chemmachery, Letessier) link the most literal meaning of reconstruction, in its embodiment of the colonial enterprise as a bricks-and-mortar form of empire-building, with the social and human ramifications of colonialism in the present. In the two other articles (Courtois, Moïse), the reconstruction involved is primarily human and concerns the body as the site of a necessary reconstruction of human relations.

Pascal Zinck examines the difficulty of reconstruction in the context of the longterm conflict between the government of Sri Lanka and the Tamil separatist guerilla (LTTE) as it is reflected in Romesh Gunesekera's story collection Noontide Toll (2014). In a collection of fourteen interlinked stories divided into two sections, "South" and "North," reflecting the division of the country between the Tamil-dominated North and the Sinhalese South, Gunesekera explores, through the words of his narrator Vasantha, the difficulty of reconciling the two populations through a "one-size-fits-all government-controlled solution to reconstruction" (90). Zinck argues that the stories' peripatetic narrator, who has set up a minibus transport business taxiing foreign visitors 
around the country, becomes himself a vehicle for expressing the difficulty of overcoming the trauma of the past. His travels allow him to reveal the hypocritical nature of the island's rehabilitation projects, like the Mattala Rajapaksa International Airport or the A9 expressway, which are simply "a travesty of reconstruction" (87) since they are not based on a genuine acknowledgement of the past and a desire to transcend it. In her article devoted to J.G. Farrell's The Siege of Krishnapur, Jaine Chemmachery studies the possible meanings of the idea of reconstruction with respect to the historical novel. Farrell's novel revisits the colonial past with what would appear to be a postmodern and/or postcolonial desire for reinterpretation. By examining the novel's historical dimension, but also its recreation of Victorian culture through the representation, for instance, of relations between men and women, or the mania for collecting, Chemmachery shows how Farrell engages in a reconstruction which reveals the social and intellectual underpinnings of the period in a way that goes well beyond a simple interest in the past. The treatment of the characters through humour and satire suggests a postcolonial desire to adopt a critical stance toward the colonial period. However, the question can be raised as to whether Farrell's real desire is to engage with the ethical concerns that one associates with postcolonial criticism, or whether he is mainly interested in adapting the story of India's colonial past to the tastes of contemporary readers. Anne-Sophie Letessier, in her study of Jane Urquhart's A Map of Glass, uses reconstruction as a prism through which to explore the complex relation of Urquhart's characters to the land, a relation which, in the novel, "disrupts the logic of binary oppositions - displacement/ emplacement, place/placelessness, rootedness/rootlessness" (110). She shows how the narrators' discursive reconstruction of the past reveals the complexity of their relation to their personal and family roots in the land, undercutting any simple idea of what it means to inhabit a place or to try to preserve it. Sylvia's narrative scrutinizes the possibility of possessing the land and questions the legitimacy of entitlement, while the land artist's Fence Lines project underlines the paradoxical nature of any attempt to represent one's relation to a place, the entire novel inviting the reader to "re-examine what it means to be in place" (117).

Cédric Courtois and Myriam Moïse approach the question of reconstruction from an overtly social point of view, observing the ways in which the gendered body becomes the site of a desire for reconstruction. Cédric Courtois studies the treatment of lesbianism in Africa in Chinelo Okparanta's novel Under the Udala Trees. He revisits the Bildungsroman, one of the best-known constructs of the western novel, to examine the ways in which Okparanta questions not only the masculine and heterosexual underpinnings of African society, but also the narrative frame that has produced an aesthetic bias which leaves little place for the experience of women. The Bildungsroman, with its emphasis on the crucial process of growing up, proves to be a form which can itself undergo reconstruction in order to accommodate the experience of a young woman growing up in a society, here Nigeria, torn by civil war and divided by ethnic and religious conflicts. The protagonist's search for personal affirmation in a society which does not accept homosexual desire reveals the need for a broader form of reconstruction as a preliminary step in seeking a redefinition of the very idea of "becoming." Myriam Moïse's concern, in her article devoted to the poetry of NourbeSe Philip and Grace Nichols, is with "the bodily and discursive reclamation and self-reconstruction" (137) undertaken by women writers belonging to the African diaspora. Using the theoretical framework suggested 
by the writings of feminist critics such as Gayatari Spivak and Luce Irigaray, who have emphasized the role of the body in the construction of female subjectivity, Moïse looks at the ways in which Philip and Nichols have attempted to recover and reaffirm the black female body. While Philip uses the tongue as a synecdoche for the body, showing how language can participate in the reconstruction of the black female body, Nichols emphasizes the need to deconstruct stereotypical images of the fat black mammy by evoking and convoking them explicitly in order to achieve a genuine authority as a black female speaking subject.

By engaging with the idea of reconstruction, the authors of these articles show that if, on the one hand, reconstruction means, in a postcolonial context, re-examining the constructedness of the past, it also implies an ability to approach the present by taking the past into account in constructive and positive ways, by establishing a dialogue with the past in which the subaltern can actually speak.

\section{Salhia Ben Messahel \\ University of Lille \\ Kathie Birat \\ University of Lorraine}

\section{Works Cited}

Shringarpure, Bahkti. "The Afterlives of Frantz Fanon and the Reconstruction of Postcolonial Studies." Journal of French and Francophone Philosophy 23.1 (2015): 113-128. 